А.Г. Тепляков

Сибирские партизаны Г.Ф. Рогова

в современной историографии: между мифом и исторической критикой

doi:10.31518/2618-9100-2021-6-16

УДК 94(47)

Выходные данные для цитирования:

Тепляков А.Г. Сибирские партизаны Г.Ф. Рогова в современной историографии: между мифом и исторической критикой // Исторический курьер. 2021. № 6 (20). С. 193-204. URL: http://istkurier.ru/ data/2021/ISTKURIER-2021-6-16.pdf
A.G. Teplyakov*

\section{Siberian Partisans of G.F. Rogov in Modern Historiography: Between Myth and Historical Criticism}

\author{
doi:10.31518/2618-9100-2021-5-16
}

How to cite:

Teplyakov A.G. Siberian Partisans of G.F. Rogov in Modern Historiography: Between Myth and Historical Criticism // Historical Courier, 2021, No. 6 (20), pp. 193-204. [Available online: http:// istkurier.ru/data/2021/ISTKURIER-2021-6-16.pdf]

Abstract. The article is devoted to the problems of mythologization and demythologization of the activities of the anarchist partisans of the Siberian ataman G. Rogov in the Soviet and post-Soviet historiography. The Red partisans of the Civil War still remain the most mythologized participants in the Russian confrontation. If the shadow sides of the activities of the Soviet partisans of the Second World War are actively studied, then the rebels of the Civil War era usually still appear under an idealized guise of fighters against exploiters and interventionists. It is characteristic that in Soviet and Russian historiography there has been a struggle between apologists and critics of the Red partisans over 100 years. Paradoxically, the assessments of Rogov's partisans, known for their atrocities, mass murders and robberies, were more objective in the early Soviet period. Even then, a relatively adequate historiographical canon was formed, which was attacked by some researchers in the late Soviet period. These historians reject the information about the extreme brutality of Rogov's partisans and believe that they should be rehabilitated as honest and brave fighters for the power of the Soviets. The controversy of apologists and critics of ataman Rogov has been particularly active in the last third of the century, and fans of this partisan are numerically predominant. Despite the publication of a large number of revealing materials, historians who sympathize with anarchism are trying to whitewash Rogov. It can be considered proven that their cohesion and publication activity form a positive attitude towards Rogov in the scientific community. However, the publications of recent years, which are based on objective archival material, suggest that historians are moving to a more critical position regarding the numerous crimes of the G.F. Rogov detachment. The author of this article also introduces unknown archive documents about the crimes of the Rogov detachment at the end of 1919, especially during the capture of Kuznetsk and Shcheglovsk in Kuzbass.

Keywords: G.F. Rogov; I.P. Novoselov; anarchists; partisans; pogroms; murders; historiography; apologetics; criticism.

The article has been received by the editor on 03.12.2021.

Full text of the article in Russian and references in English are available below.

Аннотация. Статья посвящена проблемам мифологизации и демифологизации деятельности партизан-анархистов сибирского атамана Г.Ф. Рогова в советской и постсоветской историографии. Красные партизаны Гражданской войны поныне остаются самыми мифологизированными участниками российского противостояния. Если теневые стороны деятельности советских партизан Второй мировой войны активно изучаются, то повстанцы эпохи Гражданской войны обычно до сих пор предстают в светлом облике борцов против эксплуататоров

\footnotetext{
* Тепляков Алексей Георгиевич, кандидат исторических наук, Институт истории Сибирского отделения Российской академии наук, Новосибирск, Россия, e-mail: teplyakov-alexey@rambler.ru

Teplyakov Aleksey Georgievich, Candidate of Historical Sciences, Senior Researcher, Institute of History of the Siberian Branch of the Russian Academy of Sciences, Novosibirsk, Russia, e-mail: teplyakov-alexey@rambler.ru
} 
и интервентов. Характерно, что в советской и российской историографии уже 100 лет идет борьба между апологетами и критиками красных партизан. Парадоксально, но оценки партизан Рогова, известных своими жестокостями, массовыми убийствами и грабежами, в ранний советский период были более объективными. Уже тогда был сформирован относительно адекватный историографический канон, который был атакован некоторыми исследователями в позднесоветский период. Эти историки отвергают сведения о крайней жестокости партизан Рогова и считают, что они должны быть реабилитированы как честные и храбрые борцы за власть Советов. Особенно активно полемика апологетов и критиков атамана Рогова развернулась в последнюю треть века, причем количественно преобладают поклонники этого партизана. Несмотря на публикацию большого количества разоблачительных материалов, историки, которые симпатизируют анархизму, Рогова стараются обелить. Можно считать доказанным, что их сплоченность и публикационная активность формируют в научной среде положительное отношение к Рогову. Однако публикации последних лет, которые основаны на объективном архивном материале, позволяют говорить о том, что историки переходят к более критической позиции в отношении многочисленных преступлений отряда Г.Ф. Рогова. Автор данной статьи также вводит в оборот неизвестные документы архивов о преступлениях отряда Рогова в конце 1919 г., особенно при захвате Кузнецка и Щегловска в Кузбассе.

Ключевые слова: Г.Ф. Рогов; И.П. Новоселов; анархисты; партизаны; погромы; убийства; историография; апологетика; критика.

Красные партизаны поныне остаются самыми мифологизированными участниками российского гражданского противостояния. На фоне отсутствия консенсуса в российском обществе по поводу основных событий его истории очевиден разнобой во мнениях на такое значимое в истории Сибири и Дальнего Востока явление, как партизанское движение. Парадоксально, но если теневые стороны партизанского движения периода Второй мировой войны активно изучаются ${ }^{1}$, то красные повстанцы эпохи Гражданской войны чаще всего до сих пор предстают в светлом облике борцов за народное счастье.

Современная историография отражает эту ситуацию, деля историков на апологетов и критиков партизанщины. Эта историографическая ситуация противостоит пореволюционной, когда наличие множества живых свидетелей обусловило сравнительно адекватные оценки деятельности, например, партизан крупных анархически-погромных отрядов Г.Ф. Рогова и Я.И. Тряпицына. Но в позднесоветский и постсоветский периоды ряд историков стали трактовать их деятельность все более положительным образом. Однако постепенно мифы отступают, и это отступление призвана продемонстрировать настоящая статья, автор которой ранее уже выступил с анализом деятельности Рогова и Тряпицына как теоретиков и практиков масштабных социальных чисток ${ }^{2}$, а в данной работе приводит новые факты разрушительных действий партизан, действовавших в 1919 г. на территории Алтая и Кузбасса. Знамя у анархистов было черным, но террор - красным. Новое осознание этого факта оказалось процессом небыстрым, но его историографическая фиксация может считаться состоявшейся.

Для Сибири разрушительный напор красной партизанщины олицетворяет прежде всего трагедия разгромленного роговцами в декабре 1919 г. четырехтысячного Кузнецка (ныне Новокузнецк) Томской губернии, где погибли сотни жителей. И в ранней, и в оттепельной советской историографии фигура Григория Рогова трактовалась отрицательно - как по

\footnotetext{
${ }^{1}$ Спириденков В.А. Лесные солдаты: партизанская война на Северо-Западе СССР: 1941-1944 гг. М., 2007; Гогун А. Сталинские коммандос. Украинские партизанские формирования, 1941-1944. М., 2012.

${ }^{2}$ Тепляков А.Г. Партизанские социальные чистки на востоке России в 1919-1920 гг.: роговщина и тряпицынщина // Проблемы истории массовых политических репрессий в СССР. 1953-2013: 60 лет без Сталина. Осмысление прошлого советского государства: мат-лы VIII Междунар. науч. конф. Краснодар, 2013. T. 1. С. 134-142; Тепляков А.Г. Рогов Григорий Федорович // Вожаки и лидеры Смуты. 1918-1922 гг.: биографические материалы. М., 2017. С. 452-454.
} 
причине широчайшего применения террора, так и из-за участия в антикоммунистическом восстании весной и летом 1920 г. Здесь следует отметить, что томская большевистская газета в начале 1920 г. с нескрываемым одобрением написала о том, как в Кузнецке «злая контрреволюционная гидра в 347 душ была уничтожена» роговцами ${ }^{3}$ В партийной прессе 1920-х гг. роговским погромам городов и селений Кузбасса были даны самые жесткие оценки: так, книга, посвященная 10-летию Октября в Кузнецком округе, в одном абзаце упоминала «роговскую орду», «знаменитую роговскую чистку» и «произвол роговских головорезов» ${ }^{4}$.

Затем о роговцах и роговщине писали приглушенней - как о неудобном историческом эпизоде. С оттепельных времен, когда внимание к сложным противоречивым фигурам раннесоветской эпохи вернулось, Рогова по-прежнему считали беспощадным воплощением «сибирской махновщины», но некоторые литераторы и публицисты стали трактовать его деятельность иначе, выдвигая на первый план выдающиеся победы над белыми войсками. Эта точка зрения проявилась в документальной повести Г.В. Егорова «Крушение Рогова», где герой был показан справедливым борцом за советскую власть ${ }^{5}$. В ответ на подобные публикации и активность уцелевших роговцев, требовавших своей исторической реабилитации, критическое отношение к фигуре Рогова высказали видные сибирские историки, в том числе М.Е. Плотникова ${ }^{6}$ и В.А. Кадейкин. Последний отметил, что «всюду роговцы устраивали дикую расправу над населением», а в Кузнецке осуществили «чистку», зарубив до 300 жителей. В газетной статье Кадейкин назвал роговцев «эсеро-анархистской бандой», враждебной советской власти.

Упреки в терроре и мародерстве оспаривались роговцами до самого краха коммунистической власти, в том числе бывшим под следствием в 1920 г. командиром роговского батальона В.А. Булгаковым ${ }^{8}$ (только в 1988 г. подписанное им и сотоварищами давнее письмо с протестом против «очернения» Рогова решился опубликовать академический журнал «История СССР» ${ }^{9}$, не дав к нему никаких комментариев). Под явным влиянием этих лиц вполне положительно в начале 1980-х годов начал оценивать Рогова новосибирский историк В.Т. Шуклецов, ранее писавший о нем в соответствии с историографической традицией. В монографии 1981 г. он резко изменил свое мнение о Рогове и, опираясь на некоторые тенденциозные партизанские мемуары, щедро приписывал ему руководство победоносной 10 -тысячной армией ${ }^{10}$, полностью отрицал участие как в разгроме Кузнецка, так и в майскоиюньском восстании 1920 г., утверждая, что Рогов не замешан в последнем и был убит «по недоразумению». За анархичность и жестокость партизан стал отвечать роговский соратниканархист И.П. Новоселов, совративший простоватого и искреннего ненавистника белой власти Рогова на небольшевистский путь. Автором определенно заявлялось, что следствие

\footnotetext{
${ }^{3}$ Сибирский коммунист. 1920. 22 января. С. 4.

${ }^{4}$ За десять лет. Кузнецкий округ к десятой годовщине Октябрьской революции (1917-1927). Щегловск, 1927. C. 28-29.

${ }^{5}$ Егоров Г. Крушение Рогова. Барнаул, 1965.

${ }^{6}$ Плотникова M.E. О партизанском отряде Рогова и сущности «роговщины» // Новокузнецк в прошлом и настоящем: мат-лы науч. конф., посвящ. 350-летию основания Кузнецка. Новокузнецк, 1971. С. 73.

${ }^{7}$ Кадейкин В.А. Годы огневые. Из истории гражданской войны в Кузбассе 1918-1919 гг. Кемерово, 1959. С. 9798; Кадейкин В.А. Что такое «роговщина» // Кузнецкий рабочий. 1968. 21 июня. С. 1.

${ }^{8}$ То же мы видим применительно к фигуре Я.И. Тряпицына: его партизаны, включая бывших под судом в 1920 г. в качестве проводников террора, в 50-70-е гг. написали десятки обращений в высокие инстанции с требованиями реабилитировать своего вождя, в июле 1920 г. расстрелянного за уничтожение Николаевска-наАмуре. См.: Кривенький В.В. Анархистское движение в России в первой четверти ХХ в.: теория, организация, практика. М., 2018. С. 323.

${ }^{9}$ К истории партизанского движения в Сибири // История СССР. 1988. № 4.

${ }^{10}$ На деле отряд перед конфликтом Рогова и большевика Анатолия (М. Ворожцова) имел более 4 тыс. бойцов и раскололся примерно пополам. См.: Ларьков Н.С. Партизанское движение // Историческая энциклопедия Сибири: в 3 т. Новосибирск, 2009. Т. 2. С. 579.
} 
якобы «установило непричастность командного состава партизан к погромам в Кузнецке.... ${ }^{11}$.

Под влиянием книги Шуклецова в итоговой советской монографии о красном повстанчестве фамилия Рогова упоминалась бегло: ее автор уверял, что тот отличался всего лишь «политическими колебаниями и неустойчивостью», а главным лицом в истории погромных отрядов Кузбасса, затем поднявших антисоветское восстание, был исключительно И.П. Новоселов ${ }^{12}$. Однако в советском энциклопедическом справочнике, вышедшем в том же 1983 г., Рогов и Новоселов традиционно были охарактеризованы как кулацко-анархистские элементы, а их отряд - как ставший в конце 1919 г. «анархо-бандитским» ${ }^{13}$.

В ответ на реабилитацию Рогова В.И. Шишкин привел убедительные архивные данные из разнообразных и объективных источников, доказавшие полную несостоятельность попыток Шуклецова ревизовать обвинения Рогова в терроре и мятеже ${ }^{14}$. Однако после книги и более поздней статьи Шуклецова ${ }^{15}$ многие историки и публицисты взяли на вооружение лживые мемуары роговских партизан, заявлявших, что их вожак был оклеветанным героем. Эпоха гласности и постсоветские разоблачения только подстегнули апологетов роговщины, заявлявших, что города и селения громили некие другие, «неправильные» партизаны, а Рогов был настоящим народным вождем. До сих пор это мнение популяризируется частью краеведов, опирающихся на не отвечающие научным критериям публикации воспоминаний роговцев в 1980-1990-х гг., обелявших своего вождя и себя, уверявших, что убили в Кузнецке не более 12-15 отъявленных врагов, а основной вклад в погром внесли уголовники, выпущенные из тюрьмы ${ }^{16}$. При этом игнорируются опубликованные официальные материалы революционных властей о том, что роговцы зарубили в Кузнецке от 400 до 800 человек $^{17}$.

В середине 1990-х гг. А.А. Штырбул писал, что освобождение комсостава роговского войска произошло за недоказанностью обвинений и по ходатайству населения ${ }^{18}$. На деле, судя по следственным материалам, прекращенным Томской (Новониколаевской) губЧК ${ }^{19}$, вполне доказанные погромы были расценены чекистами как закономерный красный террор, перехлесты которого не могли затмить «неоценимых услуг» партизан. Защищая роговцев, барнаульский краевед Г.Н. Безруков в 1999 г. заявил о необходимости их реабилитации как тех, «кого десятки лет незаслуженно клеймили как бандитов, пьяниц и насильников», при этом не без оснований уверяя, что обстановка в отрядах знаменитых алтайских предводителей Е.М. Мамонтова и Ф.И. Архипова «была примерно такая же, как у Рогова». Также Безруков скептически упоминал про «якобы разграбление» Щегловска с Кузнецком и якобы убийства их жителей ${ }^{20}$.

\footnotetext{
${ }^{11}$ Шуклецов В.Т. Сибиряки в борьбе за власть Советов: деятельность партии в крестьянских массах Западной Сибири в годы революции и гражданской войны. Новосибирск, 1981. С. 253-258.

${ }^{12}$ Павлов Я.С. Народная война в тылу интервентов и белогвардейцев (Руководство РКП(б) подпольной и партизанской борьбой в годы вооруженной иностранной интервенции и гражданской войны). Минск, 1983. С. 367-369.

${ }^{13}$ Партизанское движение в Сибири // Гражданская война и военная интервенция в ССР: энциклопедия. М., 1983. С. 426.

${ }^{14}$ Шишкин В.И. Еще раз о Рогове и «роговщине» // Октябрь и гражданская война в Сибири. История. Историография. Источниковедение. Томск, 1985. С. 102-126.

${ }^{15}$ Шуклецов B.T. Причернские партизаны. Кто они - герои или бандиты? (Историография и источники) // Проблемы историографии партийных организаций Сибири. Томск, 1989. С. 53-59.

${ }^{16} \mathrm{~K}$ истории партизанского движения в Сибири... С. 163; Партизанское и повстанческое движение в Причумышье 1918-1922 гг.: док-ты и мат-лы. Барнаул, 1999. С. 226-275.

${ }^{17}$ Шишкин В.И. Сибирская Вандея: вооруженное сопротивление коммунистическому режиму в 1920 году. Новосибирск, 1997. С. 71; Советская деревня глазами ВЧК-ОГПУ-НКВД: в 4 т. М., 1998. Т. 1: 1918-1922. Докты и мат-лы. С. 257.

${ }^{18}$ Штырбул А.А. Анархистское движение в Сибири в 1-й четверти XX века: антигосударственный бунт и негосударственная самоорганизация трудящихся - теория и практика. Ч. 2. (1918-1925). Омск, 1996. С. 63-64.

${ }^{19}$ Государственный архив Томской области (ГАТО). Ф. Р-236. Оп. 4. Д. 322.

${ }^{20}$ Партизанское и повстанческое движение в Причумышье... С. 11, 18, 19.
} 
Споры о том, был ли Рогов беспощадным убийцей и грабителем или же победитель белых в Причумышье и Кузбассе стал жертвой исторической клеветы, активно идут последние 30 с лишним лет, сопровождаясь вводом значимого нового материала ${ }^{21}$. Среди публикуемых источников, помимо исследовательских работ ${ }^{22}$, особенно заметны мемуары, в которых ветераны-роговцы вспоминают одно, а свидетели их похождений - совершенно иное ${ }^{23}$. Довольно критично, но все же не без прикрас показал роговцев в своем новейшем историко-документальном романе журналист К.К. Сомов ${ }^{24}$, использовавший архивные мемуары ряда роговских партизан и отнесшийся к ним с большим, чем следовало бы, доверием.

При этом основной массив современной литературы до последних лет был настроен в пользу Рогова. Даже 35 лет спустя после критики В.И. Шишкиным построений Шуклецова находятся историки, которые эмоционально принимают сторону последнего, избегая конкретики и злоупотребляя кавычками: «Еще памятна сибирская “историографическая война” периода “застоя” по личности Г.Ф. Рогова и “роговщине”, и безобразная “научная” травля с идеологическим уклоном “группой товарищей” известного исследователя, уважаемого человека В.Т. Шуклецова, научная позиция которого в отношении Рогова и “роговщины” хотя и была в чем-то уязвимой, но, в общем, не более уязвимой, чем у его оппонентов. Неумолимое время в этой “войне” уже в 1990-е гг. всех рассудило и все расставило по своим местам...» ${ }^{25}$.

В современной историографии сложилась заметная группа исследователей, сочувствующих анархистам и трактующих их действия как проявление положительной революционной энергии. Они рассматривают Рогова как патриотично настроенного и самоотверженного борца с белогвардейскими угнетателями, отвергая сведения о терроре. Современный левый историк подчеркивает, что в XXI в. «наметилась тенденция к новому “сгущению красок” вокруг... партизан-анархистов», что «современные критики “справа” подчас поминают как имена нарицательные Рогова и Тряпицына в связке, подобно тому, как раньше это делали некоторые советские критики». При этом он обоснованно указывает, что камнем преткновения сегодня является история вокруг взятия Кузнецка в декабре 1919 г. $^{26}$

В своей новейшей работе старается освободить Рогова от наиболее серьезных обвинений историк анархизма Д.И. Рублев, при этом не касаясь архивов и используя давнюю и весьма неточную работу Штырбула, а также публикации тенденциозных мемуаров некоторых роговцев. Рублев уверяет, что последние убили в Кузнецке «лишь 12 чел.», грабить им Рогов запрещал, про грабежи ходили только «слухи», конфискованное имущество раздавалось бедноте, а Щегловск они, разумеется, «освободили» ${ }^{27}$. Аналогичные утверждения можно прочитать и у еще более поверхностно знакомого с темой В.Д. Ермакова ${ }^{28}$. В только что появившейся энциклопедической, но малосодержательной статье о Рогове Д.И. Рублев, упомянув фантастическую «Барнаульскую ЧК» вместо Новониколаевской губЧК, отметил, что Н.С. Ларьков, В.И. Шишкин и А.А. Штырбул возлагают ответственность за кузнецкий погром на Рогова, а Г.Н. Безруков и А.Ю. Федоров «не столь категоричны и объясняют

\footnotetext{
${ }^{21}$ Рогов Г.Ф. (Кузнецк, декабрь 1919). Аннотированный список литературы. Новокузнецк, 2010. 87 с.

${ }^{22}$ Гришаев В.Ф. Невинно убиенные. К истории сталинских репрессий православного духовенства на Алтае. Барнаул, 2004. С. 184.

${ }^{23}$ Кушникова М. Лжегерои стихов и легенд // Наша газета. 1996. 22 окт. С. 3; Кушникова М., Тогулев В. О крестьянах-партизанах и о синдроме лжи // Кузнецкий рабочий. 1998. 20 января.

${ }^{24}$ Сомов К.К. Год Колчака (Главы из романа «Усобица»). Барнаул, 2012.

${ }^{25}$ Штырбул А.А. О некоторых тенденциях и явлениях в исследовании Гражданской войны на территории Сибири в постсоветский период историографии // Гражданская война на востоке России: взгляд сквозь документальное наследие: мат-лы ІІІ Всерос. науч.-практ. конф., посвящ. 100-летию восстановления советской власти в Сибири. Омск, 2019. С. 318-324.

${ }^{26}$ Федоров А.Ю. Революционная эпопея анархистов Григория Рогова и Ивана Новоселова // Прямухинские чтения 2017 года. М., 2018. С. 339.

${ }^{27}$ Рублев Д.И. Российский анархизм в ХХ веке. СПб., 2019. С. 395-396, 401.

${ }^{28}$ Ермаков В.Д. Анархисты на фронтах Гражданской войны 1917-1922 годов. СПб., 2018. С. 178.
} 
случившееся сложившимися обстоятельствами». При этом автор не счел нужным пояснить, что первые трое - известные историки, зато Безруков краевед, а Федоров - археолог ${ }^{29}$.

Оценивая феномен роговского террора, нельзя игнорировать тот факт, что для многих партизан принципиальным условием победы были чистки населения от всех «гадов», список которых мог быть очень широким. Само слово «чистка» было хорошо знакомо партизанам. Один из них вспоминал: «Прихода Красной армии жаждали. Но партизанам самим очень хотелось, так сказать, наложить лапу на город, т.е. произвести маленькую чистку беляков...» ${ }^{30}$ (идея о «полонении городов» была распространена и у забайкальских партизан $\left.{ }^{31}\right)$. Среди роговцев не редкостью были не только особо опасные уголовники, но и патологические садисты. Так, партизан Нормайкин, «...потрясая револьвером, часто говорил: “Если мне человека каждый день не убить - я не могу терпеть”»

Если во время следствия Рогов усиленно пытался отрицать какую-либо вину, то Новоселов был откровенней: «При моих глазах совершено убийств б[ессчет?]ное множество, я даже и указать не могу, я работал целый год и в течение этого времени не могу запомнить, сколько мною уничтожено. <..> Я признаю себя виновным в том, что в гор. Кузнецке совершено убийств при моемъ участии 40-60 жертв и я считал их жертвами революции» ${ }^{33}$. Свидетель П.Н. Морозов показывал, что Новоселов лично зарубил 27 кузнечан и угрожал смертью тем, кто пытался его остановить. А видный роговец П. Леонов в ответ на вопрос Морозова о судьбе награбленного Леоновым имущества «вместо ответа хотел меня зарубит[ь]» ${ }^{34}$. Воевавший в Причумышье по соседству с роговцами комиссар 1-го Бийского партизанского полка И.Я. Огородников так характеризовал цели и методы партизанского террора: «...Головы... рубили почем попало. Хорошо [или] плохо это, для партизан было все хорошо и верно. Чем-то нужно было заняться. <..> Этим мы задали деревенской, сельской, городской контрреволюции страсти. Они в то время не смели показать головы» ${ }^{35}$.

Огородников красноречиво описал ужас, который наводили на сельское население даже отдельные роговцы, особенно известный своей жестокостью И. Тигров (Тигра). В его мемуарах есть запись о том, как в первой половине декабря 1919 г. в с. Яминском Барнаульского уезда были задержаны подозрительные лица: «Тов. Тигра приехал нарочно расправиться с ними... Помню одного здорового мужчину по фамилии Оксенов, второй среднего роста, допросили их обоих, чем были виноваты. Тигра попросил веревку[,] руки первому связали и вывели в обширную комнату, толкнули его и давай драть нагайками со Шведо[вы]м, драли[,] драли, с одной стороны пробили кожу до крови и повернули кверху животом, тоже также [били]. Устанут[,] приглашают из публики желающих, в то время желающих можно найти много. <..> ...[Тигра] берет ухо у противника, отрезает, немного оставляет кожи, чтобы ухо не упало проч[ь], и второе ухо также. Смотрю[,] и нос тоже стал пилить ножом. $<\ldots>$ Выводят [затем жертву] наружу... у ворот и расстреляли. Пришли [назад] и второго тоже так освежовали... <...> Окончили [расправу и] собрались в город Бийск... Меня [командир партизанского отряда] тов. Бахтин призвал и предупредил, ты с ними не езди, они тебя убьют дорогой, вон какие звери. ...[Вы] не видали[,] что они здесь работали на глазах массы. Я... больше видал у них, чем ты здесь» ${ }^{36}$.

Тем не менее Огородников рискнул отправиться с роговцами и смог отговорить их от новых расправ: «Приехали в село Ложкино, где тов. Шведов жил батраком, народ хорошо

\footnotetext{
${ }^{29}$ Рублев Д.И. Рогов Григорий Федорович // Россия в Гражданской войне. 1918-1922: энциклопедия в 3 т. М., 2021. Т. 2. С. 62.

${ }^{30}$ ГАНО. Ф. П-5. Оп. 2. Д. 1168. Л. 7-8.

${ }^{31}$ Степанов Ф. Тактические уроки борьбы // Партизаны: сборник статей, партизанских и красногвардейских воспоминаний, исторических документов и боевых песен, посвященный трехлетней героической борьбе рабочих и крестьян Забайкалья за власть Советов. Чита, 1929. С. 26.

${ }^{32}$ Государственный архив Новосибирской области (ГАНО). Ф. П-5. Оп. 2. Д. 1166. Л. 59.

${ }^{33}$ ГАТО. Ф. Р-236. Оп. 4. Д. 322. Л. 24 об.

${ }^{34}$ Там же. Л. 50.

${ }^{35}$ ГАНО. Ф. П-5. Оп. 6. Д. 316. Л. 96-97.

${ }^{36}$ Там же. Л. 33.
} 
изучил, видно[,] много было у них врагов... Нашли тех друзей, которые их поддержат... собрали противников[,] должно[,] человек до тридцати и устраивают суд. Меня [выбрали] предсудом[,] они члены суда. Вырабатывают план, сначала всех обсудим, а потом будем убивать. Мы двое у окна будем убивать, а ты нам только выводи по одному человеку... <... ...Я не могу согласиться расстреливать людей[,] когда на них нет никакого материала обвинительного...». Автор подытожил данный эпизод такими словами: «Вполне могли бы расстрелять трое тридцать человек, никто бы не шелохнулся, так боялись» ${ }^{37}$.

Многочисленные и полные кровавых подробностей партизанские мемуары в изобилии представлены в сибирских архивах; давно не секретно и следственное дело в отношении Рогова и Новоселова. Но недавняя обстоятельная статья о партизанах Кузбасса беспомощно констатировала, игнорируя и опубликованные, и архивные источники: «Распространение слухов о зверствах Рогова, возможно, является провокацией местных мещан и других враждебных Советской власти лиц. Дать взвешенную оценку декабрьским событиям в Кузнецке затруднительно ввиду практически полного отсутствия документальных источников» ${ }^{38}$.

Аналогично выглядит и современная оценка примерно таких же жестоких партизанских бесчинств в Щегловске. Помимо Кузнецка, роговский террор обрушился на другие города и селения Кузбасса: Щегловск (Кемерово), Гурьевск ${ }^{39}$, Кольчугино (Ленинск-Кузнецкий). Щегловские старожилы в рассказах, записанных полвека назад, вспоминали про несколько человек, брошенных в огонь: церковнослужителей, милиционера В. Хрипатого. О числе жертв достоверной информации не приводилось: опубликованы сведения, взятые из мему-

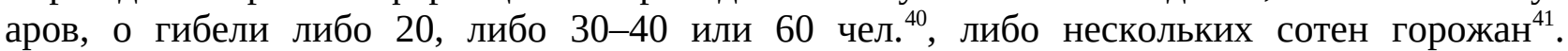
О жестоком погроме Щегловска давно упомянул современный историк ${ }^{42}$, однако в новейшей краеведческой литературе дается уклончивая оценка: «Но пока мы не можем утверждать о массовых бессудных расправах, учиненных партизанами в Щегловске» ${ }^{43}$. Между тем капитан 3-го Барнаульского полка Г.Г. Садильников, прибывший со своим полком 22 декабря в Щегловск, в дневнике записал: «В городе красные похозяйничали. Кругом по улицам валялись трупы местных горожан. В одном из домов было сложено поленницей так много обезображенных трупов с отрубленными конечностями» ${ }^{44}$.

Советский источник подтверждает эти мемуары. Учитывая сведения А.Н. Геласимовой о разоружении в городе целых воинских эшелонов, сотнях убитых и массовой ловле приезжавших в Щегловск «буржуев» и беженцев, из-за чего «пленными до отказа забили свободные дома, амбары, магазины, сараи», и ее признание, что в Щегловске было «уничтожено много колчаковцев» ${ }^{45}$, главную массу жертв составили не горожане, а взятые в плен, в том числе гражданские лица - беженцы. Геласимова записала в дневнике: «Взяли Щегловск... Что было - трудно передать. Сотни трупов» ${ }^{46}$. В неопубликованной части других своих мемуаров Геласимова откровенно написала об отношении к нескольким тысячам пленных (и, надо полагать, беженцам тоже), из которых половина была тифозных и обмороженных: «Освободили несколько домов и один на другого сваливали полуживых

\footnotetext{
${ }^{37}$ ГАНО. Ф. П-5. Оп. 6. Д. 316. Л. 34, 35.

38 Усков И.Ю., Пьянов А.Е. Партизанское движение в Кузбассе в годы Гражданской войны 1917-1919 годов // Научный диалог. 2020. № 3. С. 433.

39 Лагздин Э. На Гурьевском заводе // Сборник Истпарта. № 1. Новониколаевск, 1923. С. 104-107.

${ }^{40}$ Усков И.Ю. Рождение города. Кемерово, 2011. С. 178; Лопатин А.А. Была ли сожжена церковь в Щегловске? (мифы и действительность) // Балибаловские чтения. Мат-лы науч.-практ. конф. Кемерово, 2008. Вып. 5. С. 30-35.

${ }^{41}$ Балмасов С.С. Красный террор на востоке России в 1918-1922 гг. М., 2006. С. 260.

42 Звягин С.П. Кузбасс в годы гражданской войны. Омск, 2007. С. 58.

${ }^{43}$ Усков И.Ю. Рождение города... С. 177.

${ }^{44}$ Малеевская Т.Н., Шулдяков В.А. Последнее отступление Сибирской армии. Дневник капитана Г.Г. Садильникова (конец октября 1919 - начало марта 1920 гг.) // Известия Омского государственного историко-краеведческого музея. 2009. № 15. С. 71.

${ }^{45}$ Геласимова А.Н. Записки подпольщицы. М., 1967. С. 250.

${ }^{46}$ ГАНО. Ф. П-5. Оп. 4. Д. 1121. Л. 50.
} 
врагов...» ${ }^{47}$. Вероятно, основная часть пленных и беженцев была перебита партизанами (сотни), погибла от холода и тифа (возможно, что тысячи).

Только в самое последнее время наметился перелом в освещении кузнецкой драмы. Авторы последней известной нам статьи заявляют, что «...факты, установленные по материалам разнообразных источников, утверждают одно: в ноябре-декабре 1919 года Кузнецк был затерроризирован, разгромлен и полностью разграблен... правомерно говорить о нескольких сотнях погибших» ${ }^{48}$. Близкую позицию занял опубликовавший в конце 2020 г. большой архивный материал о Рогове Ю.И. Гончаров. Правда, его статья использует материалы следственного дела роговцев крайне выборочно, сосредоточена вокруг боевой деятельности атамана и в ней заметен привкус апологетики с желанием занизить число убитых кузнечан. Автор считает, что в Кузнецке погибло до 200 человек, примерно столько же жертв было в Кузнецком и Щегловском уездах. Однако он, используя наиболее откровенные партизанские мемуары, приводит максимальные в литературе оценки роговского террора в отношении уничтоженных в начале декабря 1919 г. защитников церкви в Тогуле - 560 убитых, включая около сотни заживо сожженных. Важно, что Ю.И. Гончаров показал, как уничтожение роговской разведки отступавшими белыми в самом конце 1919 г. резко охладило воинственность партизан, а ответом на их недисциплинированность, уход в тыл и нежелание выполнять приказы командования РККА был арест основных роговских сподвижников и разоружение его отряда красноармейцами ${ }^{49}$.

Таким образом, давно известный объективный материал о многочисленных жертвах роговщины до сих пор не воспринимается левонастроенной частью исторического сообщества, а также многими публицистами. Монографии и авторитетные справочные издания нередко воспроизводят публицистически окрашенные комплиментарные клише, реабилитируя либо скрывая преступления Г. Рогова и его соратников. Однако в последнее время не только расширилась источниковая база трагических событий в Кузнецке и других городах Кузбасса, но происходят и серьезные подвижки в переосмыслении этих событий. Массовый террор, насилия Рогова и роговцев чаще стали называть адекватными терминами. Ситуация в современной историографии роговщины свидетельствует о наличии социального заказа как на традиционную мифологию Гражданской войны, так и ее преодоление.

\section{Лumepamypa}

Балмасов С.С. Красный террор на востоке России в 1918-1922 гг. М., 2006. 384 с.

Геласимова А.Н. Записки подпольщицы М., 1967. 305 с.

Гогун А. Сталинские коммандос. Украинские партизанские формирования, 1941-1944. M., 2012. 526 с.

Гончаров Ю.И. 140 лет со дня рождения командующего партизанской армией в 1919 г. Г.Ф. Рогова (1881-1920) // Алтайский край. Календарь знаменательных и памятных дат 2021 г. Барнаул, 2021. С. 48-55.

Горбатов А.В., Мальцев М.А. Православные общины и партизанское движение в Кузбассе в 1919 году // Научный диалог. 2021. № 1. С. 224-240.

Гришаев В.Ф. Невинно убиенные. К истории сталинских репрессий православного духовенства на Алтае. Барнаул, 2004. 240 с.

Егоров Г. Крушение Рогова. Барнаул, 1965. 127 с.

Ермаков В.Д. Анархисты на фронтах Гражданской войны 1917-1922 годов. СПб., 2018. 272 c.

\footnotetext{
${ }^{47}$ ГАНО. Ф. П-5. Оп. 4. Д. 388. Л. 3.

${ }^{48}$ Горбатов А.В., Мальцев М.А. Православные общины и партизанское движение в Кузбассе в 1919 году // Научный диалог. 2021. № 1. С. 233. Здесь следует уточнить, что в ноябре терроризировался не Кузнецк, а селения уезда.

${ }^{49}$ Гончаров Ю.И. 140 лет со дня рождения командующего партизанской армией в 1919 г. Г.Ф. Рогова (18811920) // Алтайский край. Календарь знаменательных и памятных дат 2021 г. Барнаул, 2021. С. 48-55.
} 
За десять лет. Кузнецкий округ к десятой годовщине Октябрьской революции (19171927) / отв. ред. В. Ворченко. Щегловск, 1927. 79 с.

Звягин С.П. Кузбасс в годы гражданской войны. Омск, 2007. 115 с.

К истории партизанского движения в Сибири // История СССР. 1988. № 4. С. 159-170.

Кадейкин В.А. Годы огневые. Из истории гражданской войны в Кузбассе 1918-1919 гг. Кемерово, 1959. 99 с.

Кривенький В.В. Анархистское движение в России в первой четверти XX в.: теория, организация, практика. М., 2018. 430 с.

Лагздин Э. На Гурьевском заводе // Сборник Истпарта. № 1. Новониколаевск, 1923. C. 91-107.

Ларьков Н.С. Партизанское движение // Историческая энциклопедия Сибири: в 3 т. Новосибирск, 2009. Т. 2. С. 579-582.

Лопатин А.А. Была ли сожжена церковь в Щегловске? (мифы и действительность) // Балибаловские чтения. Мат-лы науч.-практ. конф. Кемерово, 2008. Вып. 5. С. 30-35.

Малеевская Т.Н., Шулдяков В.А. Последнее отступление Сибирской армии. Дневник капитана Г.Г. Садильникова (конец октября 1919 - начало марта 1920 гг.) // Известия Омского государственного историко-краеведческого музея. 2009. № 15. С. 65-84.

Павлов Я.С. Народная война в тылу интервентов и белогвардейцев (Руководство РКП(б) подпольной и партизанской борьбой в годы вооруженной иностранной интервенции и гражданской войны). Минск, 1983. 430 с.

Партизанское движение в Сибири // Гражданская война и военная интервенция в СССР: энциклопедия. М., 1983. С. 425-428.

Партизанское и повстанческое движение в Причумышье 1918-1922 гг.: док-ты и мат-лы / ред.-сост. Г.Н. Безруков. Барнаул, 1999. 319 с.

Плотникова M.Е. О партизанском отряде Рогова и сущности «роговщины» // Новокузнецк в прошлом и настоящем: мат-лы науч. конф., посвящ. 350-летию основания Кузнецка. Новокузнецк, 1971. С. 66-81.

Рогов Г.Ф. (Кузнецк, декабрь 1919). Аннотированный список литературы / сост. Т.Н. Киреева. Новокузнецк, 2010. 87 с.

Россия в Гражданской войне. 1918-1922: Энциклопедия в 3 т. М., 2021. Т. 2. 877 с.

Рублев Д.И. Российский анархизм в ХХ веке. СПб., 2019. 704 с.

Советская деревня глазами ВЧК-ОГПУ-НКВД. 1918-1939: в 4 т. М., 1998. Т. 1: 19181922. Док-ты и мат-лы. 864 с.

Сомов К.К. Год Колчака (Главы из романа «Усобица»). Барнаул, 2012. 656 с.

Спириденков B.A. Лесные солдаты: Партизанская война на Северо-Западе СССР: 19411944 гг. М., 2007. 334 с.

Степанов Ф. Тактические уроки борьбы // Партизаны: сборник статей, партизанских и красногвардейских воспоминаний, исторических документов и боевых песен, посвященный трехлетней героической борьбе рабочих и крестьян Забайкалья за власть Советов. Чита, 1929. С. 22-28.

Тепляков А.Г. Партизанские социальные чистки на востоке России в 1919-1920 гг.: роговщина и тряпицынщина // Проблемы истории массовых политических репрессий в СССР. 1953-2013: 60 лет без Сталина. Осмысление прошлого советского государства: мат-лы VIII Междунар. науч. конф. Краснодар, 2013. Т. 1. С. 134-142.

Тепляков А.Г. Рогов Григорий Федорович // Вожаки и лидеры смуты. 1918-1922 гг.: биографические материалы. М., 2017. С. 452-454.

Усков И.Ю. Рождение города. Кемерово, 2011. 352 с.

Усков И.Ю., Пьянов А.Е. Партизанское движение в Кузбассе в годы Гражданской войны 1917-1919 годов // Научный диалог. 2020. № 3. С. 423-438.

Федоров А.Ю. Революционная эпопея анархистов Григория Рогова и Ивана Новоселова // Прямухинские чтения 2017 года. М., 2018. С. 338-353. 
Шишкин В.И. Еще раз о Рогове и «роговщине» // Октябрь и гражданская война в Сибири. История. Историография. Источниковедение. Томск, 1985. С. 102-126.

Шишкин В.И. Сибирская Вандея: вооруженное сопротивление коммунистическому режиму в 1920 году. Новосибирск, 1997. 710 с.

Штырбул А.А. Анархистское движение в Сибири в 1-й четверти XX века: антигосударственный бунт и негосударственная самоорганизация трудящихся - теория и практика. Ч. 2. (1918-1925). Омск, 1996. 174 с.

Штырбул А.А. О некоторых тенденциях и явлениях в исследовании Гражданской войны на территории Сибири в постсоветский период историографии // Гражданская война на востоке России: взгляд сквозь документальное наследие: мат-лы III Всерос. науч.-практ. конф., посвящ. 100-летию восстановления сов. власти в Сибири (Омск, 13-14 ноябрь 2019 г.). Омск, 2019. С. 318-324.

Шуклецов В.Т. Причернские партизаны. Кто они - герои или бандиты? (Историография и источники) // Проблемы историографии партийных организаций Сибири. Томск, 1989. С. 53-59.

Шуклецов В.T. Сибиряки в борьбе за власть Советов: деятельность партии в крестьянских массах Западной Сибири в годы революции и гражданской войны. Новосибирск, 1981. 271 с.

\section{References}

(1983). Partizanskoe dvizhenie v Sibiri [The Partisan Movement in Siberia]. In Grazhdanskaya voyna i voennaya intervenciya v SSSR: entsiklopediya. Moscow, pp. 425-428.

Balmasov, S.S. (2016). Krasnyy terror na vostoke Rossii v 1918-1922 gg. [The Red Terror in the East of Russia in 1918-1922]. Moscow. 384 p.

Bezrukov, G.N. (ed., comp.). (1999). Partizanskoe i povstancheskoe dvizhenie v Prichumysh'e 1918-1922 gg.: dok-ty i mat-ly [The Partisan and Insurgent Movement in Prichumyshye 19181922: Documents and Materials]. Barnaul. 319 p.

Egorov, G. (1965). Krushenie Rogova [The Crash of Rogov]. Barnaul. 127 p.

Ermakov, V.D. (2018). Anarhisty na frontakh Grazhdanskoy voyny 1917-1922 godov [Anarchists on the Fronts of the Civil War of 1917-1922]. St. Petersburg. 272 p.

Fedorov, A.Yu. (2018). Revolyutsionnaya epopeya anarhistov Grigoriya Rogova i Ivana Novoselova [The Revolutionary Epic of the Anarchists Grigory Rogov and Ivan Novoselov]. In Pryamuhinskie chteniya 2017 goda. Moscow, pp. 338-353.

Gelasimova, A.N. (1967). Zapiski podpol'shchitsy [Notes of an Underground Worker]. Moscow. 305 p.

Gogun, A. (2012). Stalinskie kommandos. Ukrainskie partizanskie formirovaniya, 1941-1944 [Stalin’s Commandos. Ukrainian Partisan Formations, 1941-1944]. Moscow. 526 p.

Goncharov, Yu.I. (2021). 140 let so dnya rozhdeniya komanduyushchego partizanskoy armiey v 1919 g. G.F. Rogova (1881-1920) [140 Years Since the Birth of the Commander of the Partisan Army in 1919, G.F. Rogov (1881-1920)]. In Altayskiy kray. Kalendar' znamenatel'nykh i pamyatnykh dat 2021 g. Barnaul, pp. 48-55.

Gorbatov, A.V., Mal'cev, M.A. (2021). Pravoslavnye obshchiny i partizanskoe dvizhenie v Kuzbasse v 1919 godu [Orthodox Communities and Partisan Movement in Kuzbass in 1919]. In Nauchnyy dialog. No. 1, pp. 224-240.

Grishaev, V.F. (2004). Nevinno ubiennye. K istorii stalinskikh repressiy pravoslavnogo duhovenstva na Altae [Innocently Murdered. On the History of Stalin's Repressions of the Orthodox Clergy in Altai]. Barnaul. 240 p.

(1988). K istorii partizanskogo dvizheniya v Sibiri [On the History of the Partisan Movement in Siberia]. In Istoriya SSSR. No. 4, pp. 159-170.

Kadeykin, V.A. (1959). Gody ognevye. Iz istorii grazhdanskoy voyny v Kuzbasse 19181919 gg. [Years of Fire. From the History of the Civil War in Kuzbass 1918-1919]. Kemerovo. 99 p. 
Kireeva, T.N. (comp.) (2010). Rogov G.F. (Kuzneck, dekabr' 1919) Annotirovannyy spisok literatury [Rogov G.F. (Kuznetsk, December 1919). Annotated List of References]. Novokuzneck. $87 \mathrm{p}$.

Kriven'kiy, V.V. (2018). Anarhistskoe dvizhenie v Rossii v pervoy chetverti XX v.: teoriya, organizatsiya, praktika [Anarchist Movement in Russia in the First Quarter of the $20^{\text {th }}$ Century: Theory, Organization, Practice]. Moscow. 430 p.

Lagzdin, E. (1923). Na Gur'evskom zavode [At the Guryev Plant]. In Sbornik Istparta. Novonikolaevsk. No. 1, pp. 91-107.

Lar'kov, N.S. (2009). Partizanskoe dvizhenie [Partisan Movement]. In Istoricheskaya entsiklopediya Sibiri: v 3 t. Novosibirsk. Vol. 2, pp. 579-582.

Lopatin, A.A. (2008). Byla li sozhzhena tserkov' v Shcheglovske? (mify i deystvitel'nost') [Was the Church in Shcheglovsk Burned Down? (Myths and Reality)]. In Balibalovskie chteniya. Mat-ly nauch.-prakt. konf. Kemerovo. Vol. 5, pp. 30-35.

Maleevskaya, T.N., Shuldyakov, V.A. (2009). Poslednee otstuplenie Sibirskoy armii. Dnevnik kapitana G.G. Sadil'nikova (konets oktyabrya 1919 - nachalo marta 1920 gg.) [The Last Retreat of the Siberian Army. The Diary of Captain G.G. Sadilnikov (Late October 1919 - Early March 1920)]. In Izvestiya Omskogo gosudarstvennogo istoriko-kraevedcheskogo muzeya. No. 15, pp. 65-84.

Pavlov, Ya.S. (1983). Narodnaya voyna v tylu interventov i belogvardeytsev (Rukovodstvo RKP(b) podpol'noy i partizanskoy bor'boy v gody vooruzhennoy inostrannoy interventsii i grazhdanskoy voyny) [The People's War in the Rear of the Interventionists and the White Guards (Leadership of the RCP(b) Underground and Guerrilla Struggle During the Years of Armed Foreign Intervention and Civil War)]. Minsk. 430 p.

Plotnikova, M.E. (1971). O partizanskom otryade Rogova i sushchnosti “rogovshchiny” [About Rogov's Partisan Detachment and the Essence of the "Rogovshchina"]. In Novokuzneck v proshlom i nastoyashchem: mat-ly nauch. konf., posvyashchennoy 350-letiyu osnovaniya Kuznecka. Novokuzneck, pp. 66-81.

(2021). Rossiya v Grazhdanskoy voyne. 1918-1922: entsiklopediya $v 3$ t. [Russia in the Civil War. 1918-1922: Encyclopedia]. Moscow. Vol. 2. 877 p.

Rublev, D.I. (2019). Rossiyskiy anarhizm v XX veke [Russian Anarchism in the $20^{\text {th }}$ Century]. St. Petersburg. 704 p.

Shishkin, V.I. (1985). Eshche raz o Rogove i "rogovshchine" [Once Again About Rogov and "Rogovshchina”]. In Oktyabr' i grazhdanskaya voyna $v$ Sibiri. Istoriya. Istoriografiya. Istochnikovedenie. Tomsk, pp. 102-126.

Shishkin, V.I. (1997). Sibirskaya Vandeya: vooruzhennoe soprotivlenie kommunisticheskomu rezhimu v 1920 godu [Siberian Vendee: Armed Resistance to the Communist Regime in 1920]. Novosibirsk. 710 p.

Shtyrbul, A.A. (1996). Anarhistskoe dvizhenie $v$ Sibiri $v$ 1-j chetverti XX veka: antigosudarstvennyy bunt i negosudarstvennaya samoorganizatsiya trudyashchihsya - teoriya i praktika [Anarchist Movement in Siberia in the $1^{\text {st }}$ Quarter of the $20^{\text {th }}$ Century: Anti-State Revolt and NonState Self-Organization of Workers - Theory and Practice] (1918-1925). Omsk. Vol. 2. 174 p.

Shtyrbul, A.A. (2019). O nekotorykh tendentsiyakh i yavleniyakh v issledovanii Grazhdanskoy voyny na territorii Sibiri v postsovetskiy period istoriografii [About Some Trends and Phenomena in the Study of the Civil War in Siberia in the Post-Soviet Period of Historiography]. In Grazhdanskaya voyna na vostoke Rossii: vzglyad skvoz' dokumental'noe nasledie: mat-ly III Vseros. nauch.prakt. konf., posvyashch. 100-letiyu vosstanovleniya sov. vlasti v Sibiri. Omsk, pp. 318-324.

Shukletsov, V.T. (1981). Sibiryaki $v$ bor'be za vlast' Sovetov: deyatel'nost' partii $v$ krest'yanskih massah Zapadnoy Sibiri v gody revolyutsii i grazhdanskoy voyny [Siberians in the Struggle for Soviet Power: the Activity of the Party in the Peasant Masses of Western Siberia During the Revolution and the Civil War]. Novosibirsk. 271 p.

Shukletsov, V.T. (1989). Prichernskie partizany. Kto oni - geroi ili bandity? (Istoriografiya i istochniki) [The Taiga Guerrillas: who are They - Heroes or Bandits? (Historiography and sources)]. In Problemy istoriografii partiynykh organizatsiy Sibiri. Tomsk, pp. 53-59. 
Somov, K.K. (2012). God Kolchaka (Glavy iz romana "Usobica”) [The Year of Kolchak. Chapters from the novel "Internecine Strife"]. Barnaul. 656 p.

(1998). Sovietskaya derevnya glazami VCHK-OGPU-NKVD. 1918-1939. V 4 t. 1918-1922. Dok-ty i mat-ly [The Soviet Village Through the Eyes of the CHEKA-OGPU-NKVD. 1918-1922. Documents and Materials]. Moscow. Vol. 1. 864 p.

Spiridenkov, V.A. (2007). Lesnye soldaty: Partizanskaya voyna na Severo-Zapade SSSR: 19411944 gg. [Forest Soldiers: The Guerrilla War in the North-West of the USSR: 1941-1944]. Moscow. 334 p.

Stepanov, F. (1929). Takticheskie uroki bor'by (1929) [Tactical Lessons of Fighting] In Partizany: sbornik statey, partizanskikh i krasnogvardeyskikh vospominaniy, istoricheskikh dokumentov i boevykh pesen, posvyashchennyy trekhletney geroicheskoy bor'be rabochikh i krest'yan Zabaykal'ya za vlast' Sovetov. Chita, pp. 22-28.

Teplyakov, A.G. (2013). Partizanskie sotsial'nye chistki na vostoke Rossii v 1919-1920 gg.: rogovshchina i tryapitsynshchina [Partisan Social Purge in the East of Russia in 1919-1920: Rogovshchina and Tryapitsynshchina]. In Problemy istorii massovykh politicheskikh repressiy $v$ SSSR. 1953-2013: 60 let bez Stalina. Osmyslenie proshlogo sovetskogo gosudarstva: mat-ly VIII Mezhdunar. nauch. konf. Krasnodar. Vol. 1, pp. 134-142.

Teplyakov, A.G. (2017). Rogov Grigoriy Fedorovich [Rogov Grigoriy Fedorovich]. In Vozhaki i lidery smuty. 1918-1922 gg.: biograficheskie materialy. Moscow, pp. 452-454.

Uskov, I.Yu. (2011). Rozhdenie goroda [The Birth of the City]. Kemerovo. 352 p.

Uskov, I.Yu., P’yanov, A.E. (2020). Partizanskoe dvizhenie v Kuzbasse v gody Grazhdanskoy voyny 1917-1919 godov [The Partisan Movement in Kuzbass During the Civil War of 19171919]. In Nauchnyy dialog. No. 3, pp. 423-438.

Vorchenko, V. (1927). Za desyat' let. Kuzneckiy okrug k desyatoy godovshchine Oktyabr'skoy revolyutsii (1917-1927) [For Ten Years. Kuznetsk District on the Tenth Anniversary of the October Revolution (1917-1927)]. Shcheglovsk. 79 p.

Zvyagin, S.P. (2007). Kuzbass v gody grazhdanskoy voyny [Kuzbass During the Civil War]. Omsk. 115 p. 